\title{
EFEKTIVITAS MEDIA PEMBELAJARAN FLIP-BOOK BERBASIS SCREENCAST-O-MATIC (SOM) VIDEO SEBAGAI SYSTEM ASYNCHRONOUS PADA MAHASISWA UNIVERSITAS PASIFIK MOROTAI; STUDI KASUS DI DAERAH RURAL
}

\author{
${ }^{1}$ Balqis Husain, ${ }^{2}$ Fahmi Jaguna, ${ }^{3}$ Amrin Sibua \\ ${ }^{1,2,3}$ Universitas Pasifik Morotai, Pulau Morotai, Indonesia \\ Correspondence Email: balqishusain.bh@gmail.com
}

Received: Dec 2, 2021 Revised: Dec 10, $2021 \quad$ Accepted: Dec 15, 2021

\begin{abstract}
ABSTRAK
Tujuan dari penelitian ini yaitu untuk menganalisis efektivitas dari media Flip-Book berbasis Screencast-O-Matic Video Sebagai sistem Asynchronous untuk pembelajaran Bahasa Inggris di Daerah Rural. Metode penelitian ini menggunakan metode descriptive-quantiitative. Subjek pada penelitian ini yakni sebanyak 76 mahasiswa yang tersebar pada Program Studi Teknik Informatika, Ilmu Kelautan, Administrasi Negara, dan Akuntansi. Uji validitas dan reliabilitas dilakukan pada pengujian instrument penelitian. Instrumen penelitian menggunakan angket yang terdiri dari 31 pernyataan baik pernyataan positive maupun negative. Skala pengukuran yang digunakan pada penelitian ini menggunakan skala likert. Dari keempat aspek yang digunakan peneliti dalam mengukur efektivitas media pembelarajan Flip-book berbasis SoM video dalam proses pembelajaran bahasa Inggris, aspek kemampuan pendidik dalam mengelola pembelaran mempunyai nilai mean tersebar yaitu 44.97 dengan nilai minimum sebesar 39, dan nilai maksimum sebesar 50. Diikuti aspek aktivitas belajar dengan nilai mean sebesar 36.43, dan aspek ketuntasan belajar sebesar 31.57. sedangkan aspek sarana prasarana yang menunjang pembelajaran memiliki nilai mean terkecil yakni sebesar 27.24. dengan demikian dapat disimpulkan bahwa aspek kemampuan pendidik dalam mengelola pembelajaran merupakan aspek yang paling berpengaruh pada efetivitas media pembelarajan Flip-book berbasis SoM video dalam proses pembelajaran bahasa Inggris.
\end{abstract}

\footnotetext{
ABSTRACT

This research aims to assess the efficacy of Screencast-O-Matic Video-based Flip-Book media as an Asynchronous system for learning English in rural areas. This research method employs Descriptive-quantiitative methods. This study included 76 students from the Informatics Engineering, Marine Science, State Administration, and Accounting Study Programs. The research questionnaire was applied to validity and reliability tests. A questionnaire with 31 statements, both positive and negative, was used as the research instrument. This study's measurement scale is a Likert scale. From the four aspects used by researchers in measuring the effectiveness of Flip-book learning media based on SoM video in the English learning process, the aspect of educators' ability to manage to learn has the highest mean value of 44.97, with a minimum value of 39 and a maximum value of 50,
} 
Aspects of learning activities have a mean value of 36.43, and aspects of learning completeness have a mean value of 31.57. The aspect of infrastructure that supports learning has the lowest mean value of 27.24. As a result, it is possible to conclude that educators' ability to manage to learn has the greatest influence on the effectiveness of SoM video-based Flip-book learning media in the English learning process.

\section{PENDAHULUAN}

Tak dapat dipungkiri bahwa beberapa tahun terakhir pembelajaran berbasis teknologi (E learning) mulai mendapatkan perhatian khusus dari berbagai instituasi pendidikan maupun pelaku pendidikan di Indonesia. (L. Zhou et al., 2020) e-learning atau pembelajaran berbasis online merupakan model pembelajaran yang mendorong pengguna (siswa/guru/instruktur) memanfaatkan platform teknologi infomasi dan komunikasi dalam proses belajar mengajar. Sejalan dengan yang dikemukakan oleh Arif \& Wahyu (2014) bahwa E-learning merupakan metode belajar mengajar dengan menggunakan sebuah sistem sebagai media belajar mengajar yang terhubung oleh jaringan. Talebian et al., (2014) menekankan bahwa untuk mendorong terjadinya pembelajaran berbasis online, tenaga pengajar maupun siswa harus memanfaatkan platform pembelajaran yang sesuai dengan kebutuhan maupun kondisi pengguna tersebut. Bahkan Sulisworo et al., (2016) dan Zhou et al., (2020) sepakat bahwa pembelajaran berbasis teknologi membawa banyak manfaat dan sesuai dengan era saat ini yakni era teknologi 4.0. bahkan menurut Dwiyogo \& Radjah (2020) e-learning dapat meningkatkan wawasan yang lebih baik dan membuat daya tarik yang efisien, efektif, dan mendidik.

Pada dasarnya, e-learning memiliki dua tipe yaitu synchronous dan asynchronous. Synchronous berarti pada waktu yang sama. Proses pembelajaran terjadi pada saat yang sama antara pendidik dan peserta didik. Hal ini memungkinkan interaksi langsung antara pendidik dan peserta didik secara online. Dalam pelaksanaan, pembelajaran synchronous mengharuskan pendidik dan peserta didik mengakses internet secara bersamaan. Pendidik memberikan materi pembelajaran dalam bentuk makalah atau slide presentasi dan peserta didik dapat mendengarkan presentasi secara langsung melalui internet. Asynchronous berarti tidak pada waktu bersamaan. Peserta didik dapat mengambil waktu pembelajaran berbeda dengan pendidik pada saat memberikan materi. Pembelajaran asynchronous popular dalam e-learning karena peserta didik dapat mengakses materi pembelajaran dimanapun dan kapanpun. Peserta didik dapat melaksanakan pembelajaran dan menyelesaikannya setiap saat sesuai rentang jadwal yang sudah ditentukan. Pembelajaran dapat berbentuk bacaan, animasi, simulasi, permainan edukatif, tes, quis dan 
pengumpulan tugas (Hartanto, 2016).

Adawi (2016) Dibeberapa negara yang sudah maju dengan kondisi infrastruktur jaringan kecepatan tinggi akan sangat memungkinkan penerapan teknologi multimedia dengan menggunakan system synchronous atau secara real time seperti video conference untuk kepentingan aplikasi e-learning, tetapi untuk kondisi umum di Indonesia terutama di daerah rural dimana infrastruktur jaringannya masih relatif terbatas akan mengalami hambatan dan menjadi tidak efektif apabila diterapkan system synchronous. Sistem asynchronous memungkinkan peserta didik untuk berdiskusi dengan instruktur atau guru serta antar peserta didik melalui internet pada waktu yang berbeda. Meskipun tidak adanya interaksi di waktu yang sama tetapi kemudian, dengan penggunaan alat-alat seperti diskusi utas dan e-mail. Manfaat dari sistem pembelajaran ini bahwa peserta didik dapat belajar pada waktu, situasi dan kondisi yang memungkinkan dengan mereka sementara kerugiannya yakni bahwa peserta didik tidak dapat menerima umpan balik seketika itu juga dari instruktur serta dari rekan pelajar (Almosa \& Almubarak, 2005). Sistem pembelajaran ini dianggap sangat membantu siswa yang tinggal dari daerah pedesaan dengan koneksi internet yang buruk untuk belajar di rumah. Jenis pembelajaran ini membantu guru dalam menyampaikan materi dan meningkatkan pemahaman siswa terhadap materi yang diberikan oleh guru (Novantara \& Muhammad, 2018). Dewi (2016) meyakini bahwa faktor lain yang berperan paling menonjol dalam menentukan keberhasilan siswa saat belajar adalah kurangnya perhatian siswa terhadap materinya yang disampaikan oleh para pendidik dan media pembelajaran tidak sesuai dengan kebutuhan siswa. Melalui pembelajaran system ini, para siswa belajar secara mandiri, dan mereka diberikan sedikit waktu untuk berpikir dan memahami materi dengan tulus tanpa tekanan dari para pendidik (Suranto, 2009).

Screencast-o-matic video merupakan salah satu aplikasi yang menggunakan system asynchronous. Screencast-o-matic adalah perangkat lunak yang dapat digunakan untuk sistem pengguna Windows XP, Windows Vista dan Windows 7. Screencast-o-matic juga dapat merekam aktivitas webcam. Screen Recoder ini biasanya digunakan untuk merekam dan membagikannya melalui blog youtube maupun MP4. (Priowirjanto et.al., 2013); (Suryanto \& Sumbawati, 2015). Platform ini dapat dibagikan melalui berbagai media pembelajaran (Anjani Tiara, 2019). Screencast-o-matic adalah perangkat lunak yang dapat merekam semua media e-learning ke dalam tutorial video yang dilakukan guru seolah-olah belajar di kelas yang dapat digunakan sebagai video instruksional. 
Dalam kegiatan pembelajaran guru perlu memilih dan mengembangkan strategi pembelajaran yang melibatkan berbagai metode pencocokan, sesuai dengan unsur materi, keadaan saran dan situasi siswa. Untuk itu dalam pemilihan dan penggunaan metode pengajaran harus melibatkan siswa, memimpin siswa untuk berfikir kritis dan kreatif, itu bertumpu pada optimalisasi interaksi dalam proses pembelajaran dan optimalisasi keterlibatan semua indera. Penelitian dilakukan dengan menjadikan media pembelajaran elektronik melalui pemanfaatan Flip-Book berbasis Screencast-O-Matic video sebagai sistem asynchronous untuk meningkatkan variasi model pembelajaran Bahasa Inggris di daerah rural sebagai fasilitas untuk mendukung proses pengajaran dan pembelajaran dan bukan hanya mengimplementasikan materi ajar, tetapi juga membuat skenario yang menarik dengan keterlibatan untuk mengajak siswa aktif dan konstruktif dalam proses pembelajaran bahasa Inggris. Untuk mewujudkan e-learning yang mampu meningkatan kemampuan aspek kognitif siswa, peneliti menggunakan pendekatan kontruktivisme. Menurut pendekatan ini, kemampuan kognitif siswa akan meningkat jika dalam pembelajaran tersebut siswa sendirilah yang menemukan sendiri pemaknaan pembelajaran yang mereka lakukan.

Penelitian ini fokus untuk mengetahui efektivitas dari Flip-Book berbasis Screencast-O-Matic Video Sebagai sistem Asynchronous untuk pembelajaran Bahasa Inggris di Daerah Rural. Berbeda dengan penelitian sebelumnya yang dilakukan oleh Hasanudin et al., (2018); Kholifa (2016). Kedua peneliti sebelumnya mengacu pada pengembangan dan penerapan media pembelajaran, tanpa memperhatikan aspek keterbatasan jaringan internet di daerah rural. Saat ini, peneliti fokus untuk mengetahui efektivitas media Flip-Book berbasis Screencast-O-Matic Video Sebagai sistem Asynchronous untuk pembelajaran Bahasa Inggris di Daerah Rural, dimana tutorial pembelajaran dibagikan melalui MP4 sehingga tidak membutuhkan akses internet yang memadai dan tanpa memakan kuota internet yang besar.

\section{METODE PENELITIAN}

Metode penelitian ini menggunakan metode quantitative-descriptive, sample pada penelitian ini yakni sebanyak 76 mahasiswa yang tersebar pada Program Studi Teknik Informatika, Ilmu Kelautan, Administrasi Negara, dan Akuntansi. Uji validitas dan reliabilitas dilakukan pada pengujian instrument penelitian. Instrumen penelitian menggunakan angket yang terdiri dari 31 pernyataan baik pernyataan positive maupun negative. Skala pengukuran yang digunakan pada penelitian ini menggunakan skala likert 
dengan lima skala perhitungan yaitu sangat setuju (SS), setuju (S), ragu-ragu ( R), tidak setuju (TS), dan sangat tidak setuju (STS).

Untuk mengetahui efektivitas media pembelajaran Flip-Book Berbasis ScreencastO-Matic (SoM) Video Sebagai System Asynchronous pada mata kuliah bahasa Inggris, peneliti menggunakan angket penelitian sebagai instrument penelitian, adapun angket penelitian berdasarkan empat indicator yaitu ketuntasan belajar, aktifitas belajar, kemampuan pendidik mengelolah pembelajaran, dan ketersediaan sarana dan prasarana.

\section{A. Hasil dan Pembahasan}

Untuk mengukur efektivitas penerapan aplikasi pembelajaran flipbook berbasis SoM dengan sistem asyncronous, maka penelitian ini dilakukan di Program Studi Teknik Informatika, Ilmu Kelautan, Administrasi Negara, dan Akuntansi, pada mahasiswa aktif semester II Universitas Pasifik Morotai. Adapun sebaran mahasiswa di masing-masing prodi dapat dilihat pada tabel di bawah ini;

Tabel 1. Sebaran Sampel pada tiap-tiap PS

\begin{tabular}{|l|l|l|}
\hline No & Program Studi & Jumlah Sampel \\
\hline 1 & Teknik Informatika & 19 \\
\hline 2 & Ilmu Kelautan & 15 \\
\hline 3 & $\begin{array}{l}\text { Administrasi } \\
\text { Negara }\end{array}$ & 23 \\
\hline 4 & Akuntansi & 19 \\
\hline \multicolumn{2}{|l|}{ Total } & $\mathbf{7 6}$ \\
\hline
\end{tabular}

Berdasarkan pada tabel diatas dapat disimpulkan bahwa responden pada penelitian ini sebanyak 76 mahasiswa yang tersebar di empat Program Studi yakni Program Studi Teknik Informatika, Ilmu Kelautan, Administrasi Negara, dan Akuntansi. Dimana keseluruhan mahasiwa tersebut memperoleh mata kuliah Bahasa Inggris Umum dengan menggunakan media Flip-book berbasis SoM dengan system asynchronous.

Tabel 2. Uji Validitas pada Masing-masing Indikator

\begin{tabular}{|l|l|l|l|l|}
\hline \multicolumn{1}{|c|}{ Variabel } & \multicolumn{1}{|c|}{$\begin{array}{c}\text { Jumlah } \\
\text { soal }\end{array}$} & $\begin{array}{c}\text { Jumlah } \\
\text { Soal yang } \\
\text { valid }\end{array}$ & $\begin{array}{c}\text { r-tabel } \\
\mathbf{( 5 \% )}\end{array}$ & $\begin{array}{c}\text { Validity } \\
\text { index }\end{array}$ \\
\hline Ketuntasan belajar & 7 & 7 & 0.227 & $0.355-0.601$ \\
\hline Aktivitas Belajar & 8 & 8 & 0.227 & $0.233-0.624$ \\
\hline $\begin{array}{l}\text { Kemampuan Pendidik dalam } \\
\text { Mengelola Pembelajaran }\end{array}$ & 10 & 10 & 0.227 & $0.252-0.481$ \\
\hline
\end{tabular}




\begin{tabular}{|l|l|l|l|l|}
\hline $\begin{array}{l}\text { Sarana Prasarana yang } \\
\text { Menunjang Pembelajaran }\end{array}$ & 6 & 6 & 0.227 & $0.233-0.624$ \\
\hline
\end{tabular}

Data tersebut mengungkapkan bahwa semua pernyataan pada tiap-tiap indikator dengan jumlah keseluruhan pernyataan sebanyak 31 item dinyatakan valid. Hal tersebut dapat dilihat berdasarkan nilai r-tabel dengan tingkat kesalahan 5\% sebesar 0.227 lebih kecil dari r-hitung (r-tabel $<$ r-hitung).

Tabel 3. Uji Reliabilitas

\begin{tabular}{|l|l|c|l|}
\hline $\begin{array}{l}\text { Jumlah } \\
\text { Soal }\end{array}$ & $\begin{array}{c}\text { r- } \\
\text { hitung }\end{array}$ & $\begin{array}{c}\text { r-tabel } \\
\mathbf{( 5 \% )}\end{array}$ & Keterangan \\
\hline 31 & 0.439 & 0.227 & Reliabel \\
\hline
\end{tabular}

Nilai uji reliabilitas menunjukan bahwa r-hitung sebesar 0.439 dan r-tabel dengan tingkat kesalahan 5\% sebesar 0.227. dengan demikian, dapat disimpulkan bahwa instrument penelitian yang digunakan reliable atau konsisten.

Tabel 4. Deskripsi Aspek-Aspek Efektivitas Media Pembelajaran Flip-Book Berbasis

Screencast-O-Matic (SoM) Video sebagai System Asynchronous

\begin{tabular}{|l|c|c|c|c|}
\hline \multicolumn{1}{|c|}{ Aspek } & Mean & $\begin{array}{c}\text { Std. } \\
\text { Deviation }\end{array}$ & Minimum & Maximum \\
\hline Ketuntasan Belajar & 31.57 & 2.131 & 26 & 35 \\
\hline Aktivitas Belajar & 36.43 & 2.074 & 32 & 40 \\
\hline $\begin{array}{l}\text { Kemampuan Pendidik } \\
\text { dalam } 44.97\end{array}$ & 2.400 & 39 & 50 \\
Pembelola & & & 23 & 30 \\
\hline $\begin{array}{l}\text { Sarana Prasarana yang } \\
\text { Menunjang Pembelajaran }\end{array}$ & 27.24 & 1.825 & & \\
\hline
\end{tabular}

Data diatas menunjukan bahwa empat aspek yang digunakan oleh peneliti dalam mengukur efektivitas media pembelarajan Flip-book berbasis SoM video. Dari keempat aspek tersebut, aspek kemampuan pendidik dalam mengelola pembelaran mempunyai nilai mean tersebar yaitu 44.97 dengan nilai minimum sebesar 39, dan nilai maksimum sebesar 50. Diikuti aspek aktivitas belajar dengan nilai mean sebesar 36.43, dan aspek ketuntasan belajar sebesar 31.57. sedangkan aspek sarana prasarana yang menunjang pembelajaran memiliki nilai mean terkecil yakni sebesar 27.24. dengan demikian dapat disimpulkan bahwa aspek kemampuan pendidik dalam mengelola pembelajaran 
merupakan aspek yang paling berpengaruh pada efetivitas media pembelarajan Flip-book berbasis SoM video dalam proses pembelajaran bahasa Inggris.

Sejalan dengan penelitian lain yang dilakukan oleh (Roemintoyo \& Budiarto, 2021), penelitian ini bertujuan untuk mengidentifikasi peluang pengembangan media pembelajaran berbasis flipbook yang terintegrasi dengan teknologi dengan harapan untuk meningkatkan keterampilan literasi sains. Hasil penelitian ini menunjukkan bahwa siswa memiliki persepsi positif terhadap peluang untuk mengembangkan dan memanfaatkan flipbook sebagai media pembelajaran digital. Melalui hasil penelitian ini dapat menjadi dasar bagi pendidik dalam mengembangkan dan mengimplementasikan media pembelajaran digital berbasis flipbook untuk mempermudah proses pembelajaran. (Abror et al., 2020) pada hasil penelitiannya mengungkapkan bahwa Media pembelajaran flipbook digital yang dikembangkan telah berhasil meningkatkan nilai siswa secara signifikan serta berhasil sebagai media penyampaian informasi kepada siswa di dalam kelas. (Susanti et al., 2020) penggunaan modul elektronik berbasis kontekstual dengan menggunakan aplikasi flipbook dalam pembelajaran dapat meningkatkan hasil belajar siswa. (Rasiman \& Pramasdyahsari, 2014) menerapkan media pembelajaran matematika e-comic berbasis flip book maker pada mata pelajaran matematika. Hasil menunjukan bahwa media tersebut efektif untuk meningkatkan kemampuan berpikir kritis siswa dan dapat menumbuhkan nilai karakter seperti: disiplin, kerjasama , kejujuran, kepercayaan diri dan ketekunan. Berbeda halnya dengan yang diungkapakan oleh (R. Zhou \& Chen, 2021), mayoritas peserta didik lebih cenderung pada pembelajaran campuran (online dan offline). pembelajaran campuran dianggap dapat memperluas lingkup belajar dengan menyediakan pembelajaran yang interaktif dan pengalaman membangun komunitas. (Henra et al., 2021) dalam penelitiannya menerapkan system pembelajaran asynchronous dengan menggunakan aplikasi Google-classroom, hasil penelitiannya menunjukan bahwa pembelajaran berbasis system jaringan asynchronous memiliki pengaruh terhadap tingkat pemenuhan capaian perkuliahan mata kuliah. Sedangkan menurut (Putri, 2020) untuk mengukur kemampuan berfikir kritis dan komunikasi, model pembelajaran dengan discovery learning berbasis aplikasi SoM sangat efektif untuk digunakan. penggunaan screen recorder (SoM) efektif dalam membantu proses pembelajaran di dalam kelas. Setelah video tutorial diberikan kepada siswa, tidak ada lagi keluhan mengenai masalah teknis, karena video tutorial dapat diputar berulang-ulang. Setelah video diunduh, siswa dapat memutarnya meskipun koneksi internet tidak stabil. Dalam hal ini, perekam layar juga dapat lebih menghemat konsumsi kuota internet (Wiradimadja et al., 2021). 
Penerapan media Screencast-o-matic membuat pembelajaran lebih efektif (Dewi, 2016). Temuan lain yang dikemukakan oleh (Basri et al., 2020) SoM melalui system asynchronous memfasilitasi mahasiswa EFL untuk meningkatkan kecakapan berbahasa dan dapat berkontribusi pada kemahiran dalam penggunaan TIK. Pada dasarnya, elearning dapat meningkatkan pemahaman dan hasil belajar siswa, tetapi pembelajaran ini tampaknya tidak efisien karena keterbatasan anggaran internet. Peran pemerintah memang signifikan, terutama dalam pengadaan sarana dan prasarana untuk mendukung proses pembelajaran e-learning (Endah Wulantina, 2019).

Pada masa penyebaran covid-19 proses belajar mengajar mengalami perubahan yang signifikan yang awalnya dominan pada pembelajaran tatap muka di kampus, saat ini beralih ke pembelajaran dengan system online, selain itu, terjadi peningkatan penggunaan teknologi dalam proses pembelajaran (Alfonsius, 2021). (Komang \& Astini, 2020) mengungkapkan beberapa kendala yang dialami mahasiswa pada saat proses perkuliahan berbasis online diterapkan secara serentak sejak adanya pandemi, fasilitas menjadi kendala utama; $50 \%$ responden belum memiliki perangkat teknologi seperti labtop dan $80 \%$ responden menyatakan infrastruktur jaringan yang tidak memadai serta borosnya penggunaan paket internet dikarenakan sebagian besar mahasiswa berasal bukan dari daerah perkotaan. Sehingga penggunaan teknologi dianggap kurang efektif. Meskipun demikian, penggunaan teknologi pembelajaran memicu percepatan transformasi digital di Indonesia pada era pendidikan 4.0.

Kompetensi digital menjadi tren baru yang harus dimiliki guru maupun siswa dalam pembelajaran era digital, karena kompetensi digital melibatkan dua aspek sekaligus yaitu aspek kepercayaan diri dan pemanfaatan informasi serta kompetensi berkomunikasi (Putri, 2020). Transformasi digital dapat membangun pengetahuan guru , oleh karena itu tenaga pendidik dapat memperkuat soft skill melalui lokakarya, peningkatan pelatihan, dan pembelajaran mandiri untuk meningkatkan kualitas pengajaran (Sulisworo et al., 2016). Selanjutnya, beberapa ide ditawarkan untuk mengatasi berbagai fenomena yang terjadi ketika mengimplementasi e-learning selama penyebaran Covid-19. Meningkatkan minat siswa dalam menggunakan e-learning; menyediakan sumber belajar; Menyediakan waktu tambahan; mengembangkan platform atau perangkat lunak untuk beberapa disiplin ilmu yang membutuhkan lebih banyak pengalaman praktis; dan melakukan pelatihan dan sosialisasi secara terus menerus untuk semua civitas akademika untuk meningkatkan kemampuan TIK mereka (Husain, Idi, et al., 2020). Ditinjau dari persepsi orang tua, elearning tidak terlepas dari pandangan negative seperti peran guru sebagai pendidik sudah 
berkurang karena hampir semua peran guru digantikan oleh orang tua; 99\% orang tua setuju bahwa pembelajaran konvensional lebih efektif dibandingkan pembelajaran berbasis elektronik; $76 \%$ orang tua menyatakan bahwa hubungan antara orang tua, siswa, dan guru kurang kooperatif pada saat proses pembelajaran berbasis online di lakukan; mata pelajaran Matematika, Fisika, serta Bahasa Inggris, dianggap sebagai mata pelajaran yang sulit untuk diajarkan pada kelas virtual; sebagian besar orang tua dari peserta didik merupakan keluarga berpenghasilan dan berpendidikan rendah, sehingga kepemilikan perangkat elektronik, biaya Internet yang tinggi, dan soft skill orang tua dalam mengoperasikan e-learning guna membantu anak mereka untuk secara aktif belajar jarak jauh adalah masalah yang signifikan, kendala lainnya koneksi internet buruk di daerah pedesaan, serta kecenderungan siswa untuk menggunakan model pembelajaran ini. Beberapa orang tua berasumsi bahwa anak-anak tidak siap untuk mengubah gaya belajar pada saat yang sama (Husain, Kofia, et al., 2020).

\section{KESIMPULAN}

Dari keempat aspek yang digunakan peneliti dalam mengukur efektivitas media pembelarajan Flip-book berbasis SoM video dalam proses pembelajaran bahasa Inggris, aspek kemampuan pendidik dalam mengelola pembelaran mempunyai nilai mean tersebar. Dapat disimpulkan bahwa teknik dalam mengelola pembelajaran memberikan pengaruh yang sangat signifikan terhadap suksesnya proses belajar-mengajar dalam kelas. Untuk itu, penting bagi setiap tenaga pendidik meninjau sejauh mana tenaga pendidik mengelolah kelas menjadi lebih menarik, interaktif, efisien dan efektif terutama pada saat mengelolah pembelajaran dengan system e-learning. Selain itu, proses mentransfer ilmu pengetahuan akan berjalan maksimal apabila tenaga pendidik memperhatikan kebutuhan, gaya belajar, lingkungan maupun kondisi siswa yang berkesesuaian dengan media yang akan di terapkan.

\section{DAFTAR PUSTAKA}

Abror, M., Suryani, N., \& Ardianto, D. T. (2020). Digital Flipbook Empowerment as A Development Means for History Learning Media. JPI (Jurnal Pendidikan Indonesia), 8(2), 266. https://doi.org/10.23887/jpi-undiksha.v8i2.24122

Adawi, R. (2016). Pembelajaran berbasis E-Learning. digilib.unimed.ac.id/541/1/Pembelajaran Berbasis E-Learning.pdf

Alfonsius, A. (2021). Penyelenggaraan Pembelajaran Perguruan Tinggi Swasta Di Masa Pandemi Covid-19. Journal of Accounting and Management ..., 5(1), 1-10. https://ejournal.medan.uph.edu/index.php/jam/article/view/434 
Anjani Tiara. (2019). Pengembangan Video Pembelajaran Screencast O-Matic Mata Pelajaran Matematika Berbasis Kurikulum 2013 pada Kelas VIII SMP Negeri 15 Semarang. https://lib.unnes.ac.id/33423/

Arif, B., \& Wahyu, P. (2014). Sistem Broadcast Proses Belajar Mengajar dengan Synchronous dan Asynchronous. Jurnal Sarjana Teknik Informatika, 2(1), 78-90. https://doi.org/10.12928/jstie.v2i1.2605

Basri, M., Husain, B., \& Modayama, W. (2020). University Students 'Perceptions in Implementing Asynchronous Learning During Covid-19 Era. METATHESIS Journal of English Language, Literature, and Teaching, 4(3), 263-276. https://doi.org/10.31002/metathesis.v4i3.2734

Dewi, S. V. (2016). Efektivitas Penggunaan Media Screencast O-Matic pada Mata Kuliah Kalkulus Integral terhadap Hasil Belajar Mahasiswa. Jurnal Penelitian Pendidikan Dan Pengajaran Matematika, 2(1), 61-66. http://jurnal.unsil.ac.id/index.php/jp3m/article/view/157

Dwiyogo, W. D., \& Radjah, C. L. (2020). Effectiveness, Efficiency and Instruction Appeal of Blended Learning Model. International Journal of Online and Biomedical Engineering, 16(4), 91-108. https://doi.org/10.3991/ijoe.v16i04.13389

Endah Wulantina, S. M. (2019). Persepsi Peserta Didik terhadap Metode Blended Learning dengan Google Classroom. Jurnal Inovasi Matematika, 1(2), 110-121. https://doi.org/10.35438/inomatika.v1i2.156

Fahmi, S., Priwantoro, S. W., Cahdriyana, R. A., Hendroanto, A., Rohmah, S. N., \& Nisa, L. C. (2019). Interactive Learning Media Using Kvisoft Flipbook Maker for Mathematics Learning. Journal of Physics: Conference Series, 1188(1). https://doi.org/10.1088/1742-6596/1188/1/012075

Hartanto, W. (2016). Penggunaan E-Learning Sebagai Media Pembelajaran. Jurnal Pendidikan Ekonomi, 10(1), 1-18. https://jurnal.unej.ac.id/index.php/JPE/article/view/3438

Hasanudin, C., Fitrianingsih, A., \& .. (2018). The Implementation of Flipped Classroom using Screencast-O-Matic to Improve Students' Verbal Linguistic Intelligence. International Journal of Engineering \& Technology, 7(4.15), 435. https://doi.org/10.14419/ijet.v7i4.15.23602

Henra, K., Tayibu, N. Q., \& Masliah, I. N. (2021). Pengaruh Pembelajaran Daring Asynchronous Terhadap Tingkat Pemenuhan CPMK Statistika. JIPM (Jurnal Ilmiah Pendidikan Matematika), 10(1), 100. https://doi.org/10.25273/jipm.v10i1.8537

Husain, B., Idi, Y. N., \& Basri, M. (2020). Teachers' Perceptions on Adopting e-Learning during COVID-19 Outbreaks; Advantages, Disadvantages, Suggestions. Jurnal Tarbiyah, 27(2), 41-57. https://doi.org/http://dx.doi.org/10.30829/tar.v27i2.738

Husain, B., Kofia, M. I., Basri, M., \& Mahmud, N. (2020). Parents' Perception on Implementing E-Learning During New Normal Era At Rural School. Jurnal IKA PGSD (Ikatan Alumni PGSD) UNARS, 8(2), 429. https://doi.org/10.36841/pgsdunars.v8i2.845

Kholifah, S. (2016). The Development of Learning Video Media Based on Swishmax and Screencast O-Matic Software through Contextual Approach. Dinamika Pendidikan, 11(1), 67-74. https://doi.org/10.15294/dp.v11i1.8701

Komang, N., \& Astini, S. (2020). Tantangan Dan Peluang Pemanfaatan Teknologi Informasi Dalam Pembelajaran Online Masa Covid-19. Cetta: Jurnal Ilmu Pendidikan, 3(2), 241-255. http://jayapanguspress.penerbit.org/index.php/cetta/article/view/452/446

Novantara, P., \& Muhammad, A. (2018). Implementasi E-Learning Berbasis Virtual Class dengan Menggunakan Metode Synchronous Learning pada Pembelajaran di 
Universitas Kuningan. Jurnal Ilmiah Teknik Informatika, 4(1), 1-7.

https://doi.org/https://doi.org/10.25134/buffer.v4i1.1290

Putri, H. dian. (2020). THE IMPLEMENTATION OF DISCOVERY LEARNING BY USING

SCREENCAST-O-MATIC APPLICATION ON STUDENTS' CRITICAL

THINKINGAND COMMUNICATIONSKILLSIN LEARNING CLIMATE CHANGE.

https://core.ac.uk/reader/346338420

Rasiman, \& Pramasdyahsari, A. S. (2014). Development of Mathematics Learning Media

E- Comic Based on Flip Book Maker to Increase the Critical Thinking Skill and

Character of Junior High School Students. International Journal of Education, 2(11),

535-544. http://eprints.upgris.ac.id/349/

Roemintoyo, R., \& Budiarto, M. K. (2021). Flipbook as Innovation of Digital Learning Media: Preparing Education for Facing and Facilitating 21st Century Learning. Journal of Education Technology, 5(1), 8. https://doi.org/10.23887/jet.v5i1.32362

Sulisworo, D., Nasir, R., \& Maryani, I. (2016). Identification of Teachers' Problems in Indonesia on Facing Global Community. International Journal of Research Studies in Education, 6(2), 81-90. https://doi.org/10.5861/ijrse.2016.1519

Suranto, B. (2009). Virtual Classroom : Strategi Pembelajaran Berbasis Synchronous ELearning. Seminar Nasional Aplikasi Teknologi Informasi 2009, 2009(20 Juni), D-78D-86. https://journal.uii.ac.id/Snati/article/viewFile/1221/1009

Suryanto, H., \& Sumbawati, M. S. (2015). Pengembangan Multimedia E-Learning Berbasis Screencast-O-Metic pada Pembelajaran Matematika untuk Siswa Sekolah Menengah Pertama Kelas VII. Jurnal Teknologi Pembelajaran Devosi, 5(3), 11-21. http://jurnal.unipasby.ac.id/index.php/devosi/article/view/544

Susanti, N., Yennita, Y., \& Azhar, A. (2020). Development of Contextual Based Electronic Global Warming Modules Using Flipbook Applications as Physics Learning Media in High Schools. Journal of Educational Sciences, 4(3), 541. https://doi.org/10.31258/jes.4.3.p.541-559

Talebian, S., Mohammadi, H. M., \& Rezvanfar, A. (2014). Information and Communication Technology (ICT) in Higher Education: Advantages, Disadvantages, Conveniences and Limitations of Applying E-learning to Agricultural Students in Iran. Procedia - Social and Behavioral Sciences, 152, 300-305. https://doi.org/10.1016/j.sbspro.2014.09.199

Wiradimadja, A., Ratnawati, N., Kurniawan, B., Yaniafari, R. P., \& Alivi, J. S. (2021). Screen Recorder for Guiding Distance Learning Case Study of Teacher Professional Education Program. International Journal of Emerging Technologies in Learning, 6(7), 4-15.

https://web.p.ebscohost.com/abstract?direct=true \&profile=ehost\&scope=site \&authtyp $\mathrm{e}=$ crawler\&jrnl $=18630383 \& \mathrm{AN}=149743818 \& \mathrm{~h}=\mathrm{UlRdnAzXpSrGU7HH} 4 J 9 Z q E h F T b$ MIV\%2B73GmzOXzVC003oSc8VfOFOAKh5rGQT\%2FNmUVcjM6TJrE7nlUmYI pPILCw\%3D\%3D\&crl=c\&resultNs=AdminWebAuth\&resultLoca

Zhou, L., Wu, S., Zhou, M., \& Li, F. (2020). 'School's Out, But Class' On', The Largest Online Education in the World Today: Taking China's Practical Exploration During The COVID-19 Epidemic Prevention and Control As an Example. SSRN Electronic Journal, 4(2), 501-519. https://doi.org/10.2139/ssrn.3555520

Zhou, R., \& Chen, D. (2021). Assessing Students ' Perceptions of Blended Learning during the COVID-19 Pandemic1 Pandemic 1. NACTA Journal, 65(936), 50-56. https://www.researchgate.net/profile/Danhong-Chen2/publication/355378429_Assessing_Students'_Perceptions_of_Blended_Assessing_ Students'_Perceptions_of_Blended_Learning_during_the_COVID19_Pandemic/links/616d81d3b90c51266263f7bc/Assessing-Students-Percept 
